\title{
Correspondence
}

\section{Reprint Communication}

SIR, One of the important communication chains in science is the distribution of reprints by the author of a published journal article. Authors differ widely in their habits of reprint distribution: some send out groat quantities wholesale, while others modestly send out just a few or even none.

We writo to plead that authors at least send roprints to living authors of works in the bibliography of the reprinted article. Both of us have had the surprising experience of discovering much later that one of our publications had been cited in an article that we would have wished to study carlier.

The reasons for sending reprints to cited authors are, as we see them, first courtesy, and second (more important) using a bibliographical connexion to help movo information along the network of scientific connexions. Distribution of reprints to previous authors increases the opportunities for serious criticism and communication of curront developments. The earlier author will have often become an information centre for his specialized subject.

Yours faithfully,

William Kruskat,

1. RICHAIRI SAVAGE

Center for Advanced Study in

the Behavioral Sciences,

202 Junipero Sorra Boulevard,

Stanford, California 94305, USA.

\section{Scientific Responsibility}

SIR,-Regarding Dr Sickevitz's article (Nature, 227, $1301 ; 1970$ ), I should like to point out that it is no use discussing scientific responsibility without first making clear what value judgments are accepted when defining responsibility. Value judgments are related to what one considers the ultimate end of existence and the following analysis might prove helpful.

In the classical view of the world, which was accepted also by science up to, say, the middle of this century, human existenco was considered as a given and static fact. In those conditions, metaphysical analysis leads to the conclusion that the aim of being is being, as Schopenhauer so brilliantly demonstrated. In other words, no other aim can be found for an individual (or collective) existence than to go on to exist. It is easy to show that all desires, aims and pleasures can in fact be reduced to this one aim, behind which no other hidden finality can be discovered. But because being in this world cannot realize its final goal, all existence having an end, this view is self-destructive, as are our ethics and the society which are derived from it. The only escape is to deny the reality of existence and to transpose it in another non-physical world. However, as science increased the scope of physical explanations and consequently appeared to increase the reality of physical existence, this route of escape became less and less plausible.

Because science also increased the power of human beings, it enabled them to pursue their aim with greater and greater destructiveness, without coming any nearer to it. This, in short, is the reason for the present unrest.

Science itself offers a ray of hope. It stems from the discoveries of Darwin, the implications of which are only now, one hundred years later, being fully grasped. The view of the world as a world of evolution enables us to conclude that the aim of boing is becoming. This is, of course, what Julian Huxloy, Bortrand Russell and Teilhard de Chardin have said before, and contrary to the former view that the aim of being is being, it is not selfdestructive. What is perhaps not so easily appreciated are the very important practical consequences of such a philosophy for everyday life. For it follows immediately that every individual is responsible not only for his oxistence, but for all future existence, which is much more important in quantity and quality. This means a shift of emphasis from "rights" to "duties", from exploitation to conservation, from (material) living standard to ecological reality, from consumption to recycling, from economics to biology. It means more and not less science, but it means the end of politics, business, economics, and trade unions as we know them.

By the way, it means the end of war as understood by Dr Siekevitz, but his obsession with this problom looks trivial when one considers the much more formidable problems which must be solved before.

Finally, it enables us to distinguish without difficulty between sincere and insincere contestation; the former defining new duties, the latter seeking new rights.

$$
\text { Yours faithfully, }
$$

17 a rue de la Senne,

S. V. VAECK

1000 Brussels, Belgium.

\section{Accelerating Somatic Cell Genetics}

SIR,-Under the above title you write (Nature, 228, 318; 1970): "The standard tochniquo for detecting linkage between human genes and assigning them to particular chromosomes involves corrolating the chromosomal make-up with the biochemical properties of interspecific hybrid cells"'.

I think it is a little premature to refer so soon to this technique as "standard", and to do so-however unintentionally -is to slight the work of those 'who have given us most of what we know about the linkage map of man. I refer to the standard method of observing segregations in families, and inferring from them linkage groups and map distances. This has been at its most successful in the assignment of loci to the $X$ chromosome, but several autosomal linkage groups have been established, and in some cases assignments to particular autosomes are well supported, the scgregation data then being supplemented by cytological information.

The hybridization technique is a most important new development, but its very novelty precludes the use of the word "standard" to describe it.

\section{Yours faithfully,}

Department of Human Ecology,

\section{A. W. F. EDwards}

University of Cambridge.

\section{Definition of Molecular Weight}

Srr,-Many biologists are now using the dalton as a unit of mass, but according to information from Dr W. E. Cohn, no Commission of any of the International Scientific Unions, or indeed any other body, has officially recognized this unit. Its usage brings again into discussion the question of the definition of molecular weight and the most appropriate units to express it.

What is the dalton? Its meaning is clcar from usage and from current definitions of standards of atomic weight ${ }^{1}$. 